\title{
NELINEARNO PONAŠANJE ZGRADA PODVRGNUTIH MONOTONO RASTUĆEM BOČNOM OPTEREĆENJU
}

\author{
NONLINEAR BEHAVIOR OF BUILDINGS SUBJECTED \\ TO MONOTONICALLY INCREASING LATERAL LOAD
}

\author{
Ana-Marija Ivanko*, Ivan Kraus*, Lucija Kraus*
}

\begin{abstract}
Sažetak
Rad obuhvaća parametarsku studiju i primjenu nelinearne metode N2 za ocjenu potresnog ponašanja četverokatne i osmerokatne armiranobetonske okvirne konstrukcije. $U$ istraživanju su korištene tri raspodjele horizontalnog opterećivanja konstrukcije potresnim silama: trokutasta (linearna), jednolika i modalna. Također, istražen je utjecaj P-Delta učinka na ponašanje promatranih konstrukcija.
\end{abstract}

Ključne riječi: metoda postupnog guranja, metoda N2, potresni proračun, nelinearno ponašanje, zgrada, P-delta učinak, plastični zglob

\begin{abstract}
The paper presents a parametric study and the application of the nonlinear N2 method for the evaluation of the seismic behavior of a four-story and an eight-story reinforced concrete frame structure subjected to seismic action. Three distributions of the horizontal loading of the structure by seismic forces were used in the study: triangular (linear), uniform and modal. The influence of the P-delta effects on seismic behavior of the observed structures was also investigated.
\end{abstract}

Keywords: pushover method, N2 method, seismic analysis, nonlinear behavior, building, P-delta effect, plastic hinge

* Građevinski i arhitektonski fakultet Osijek

E-mail: anamivanko@gmail.com; ikraus@gfos.hr; $\underline{\text { lucija@gfos.hr }}$ 


\section{Uvod}

Građenje u potresnim područjima zahtjeva interdisciplinarni inženjerski pristup i primjenu kvalitetnih materijala, optimalno raspoređenih u konstrukciji, radi ostvarivanja najviše moguće razine sigurnosti, ali i programiranog trošenja potresne energije u konstrukciji.

Radi preciznijeg određivanja potresnog ponašanja konstrukcija i za postizanje bolje kontrole oštećenja konstrukcija pri djelovanju potresa uveden je nelinearni proračun. Metoda N2 je nelinearna statička metoda za projektiranje zgrada izloženih djelovanju potresa, koja daje dobar uvid u globalno potresno ponašanje konstrukcije i dobru kontrolu nad potencijalnim mjestima nastanka plastičnih zglobova. Iako proračun konstrukcija primjenom ove metode uz neznatan dodatni trud može dati informacije o ponašanju konstrukcije od velikog značaja, metoda N2 se u praksi rijetko primjenjuje.

Ovaj rad obuhvaća primjenu metode N2 na dvije pravilne armiranobetonske okvirne konstrukcije. Obje konstrukcije su opterećivane bočnim monotono rastućim opterećenjem, primjenjujući tri različite raspodjele horizontalnog opterećenja po visini građevine, kojim se simulira potresno djelovanje [1], [2]: trokutasta (linearna), jednolika i modalna. U radu je istražen utjecaj oblika raspodjele horizontalnog opterećenja na odziv konstrukcije i procjenu potresnog kapaciteta. U radu je istražen i pokazan utjecaj postupnog povećavanja bočnih sila na promjenu krutosti konstrukcije. Odabrana četverokatna armiranobetonska okvirna konstrukcija je preuzeta iz [3], dok je osmerokatna armiranobetonska konstrukcija preuzeta iz [1].

Za svaku promatranu konstrukciju provedena je modalna analiza te nelinearni pseudo-statički proračun. Za proračun je korišten računalni program SAP2000 [4].

\section{Metoda N2}

Kako bi se prilikom projektiranja inženjerskih građevina više pažnje dalo kontroli oštećenja, potrebno je uvesti nelinearni proračun [2], [5]. Metoda N2 (N je oznaka za nelinearni proračun, a 2 da se radi o dva matematička modela) se provodi kombiniranjem nelinearne metode postupnog guranja na sustavu $s$ više stupnjeva slobode i proračuna primjenom spektara odziva. U okviru N2 metode, direktno se uspoređuje potresni kapacitet konstrukcije i potresni zahtjev, koji se određuje za područje na kojemu se gradi. Kako bi N2 metoda bila primjenjiva, konstrukcija koja se analizira mora oscilirati pretežito u prvom obliku, tj. mora imati izraženi prvi period osciliranja [6], [7]. 
Prethodno proračunu primjenom metode N2 potrebno je prikupiti osnovne podatke o geometriji i materijalu konstrukcije te, ovisno o potresnom području na kojemu se gradi, odrediti potresni zahtjev, tj. elastični spektar odziva (Slika 1).
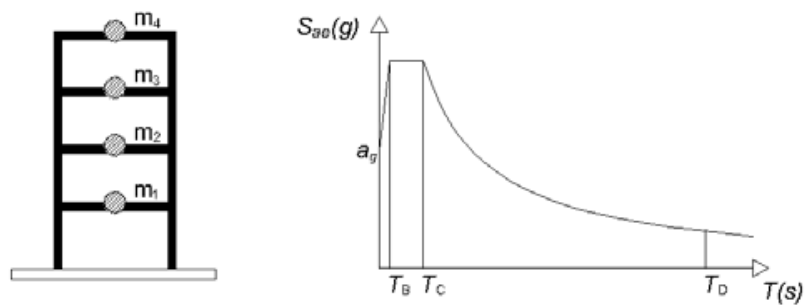

Slika 1. Primjer modela konstrukcije (lijevo) i potresni zahtjev (desno) (prema[6])

Nakon prikupljanja podataka o konstrukciji i definiranja potresnog zahtjeva, na numeričkom modelu konstrukcije provodi se nelinearna statička metoda postupnog guranja. Metoda postupnog guranja se provodi tako da se konstrukcija podvrgne monotono rastućem bočnom opterećenju. Bočno opterećenje predstavlja inercijalne sile, koje se javljaju pri djelovanju potresa na konstrukciju. Pomoću izraza (1) određuje se bočno opterećenje raspodijeljeno u razinama međukatnih konstrukcija [1], [7]:

$$
P_{i}=p m_{i} \Phi_{i}
$$

gdje $P_{i}$ odgovara $i$-toj bočnoj sili, $p$ označava intenzitet bočnog opterećenja, $m_{i}$ predstavlja masu na $i$-tom katu, a $\Phi_{i}$ pretpostavljeni oblik pomaka.

Metodom postupnog guranja se određuje krivulja kapaciteta, tj. krivulja odnosa poprečne sile u razini temelja $V$ i pomaka na vrhu zgrade $D_{\mathrm{t}}$ (Slika 2). Krivulju kapaciteta je moguće odrediti posebno za svaki kat [7].
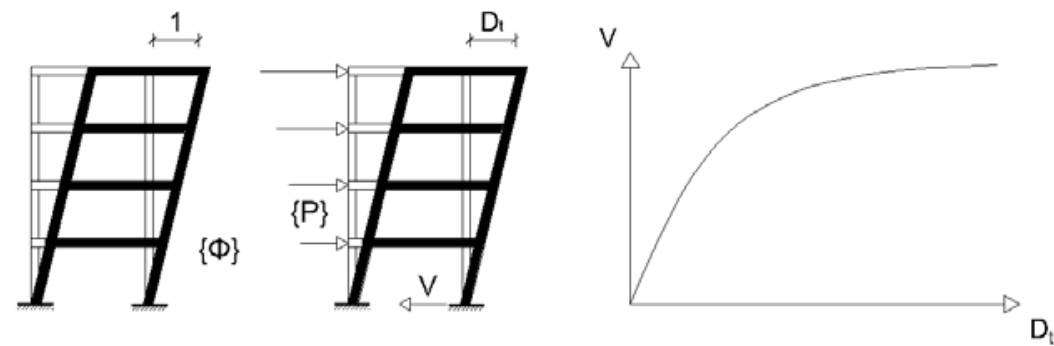

Slika 2. Pretpostavljeni oblik pomaka (lijevo), varijanta bočnog opterećenja (sredina) i dijagram kapaciteta (desno) (prema [6]) 
Budući da su spektri odziva dobiveni za sustave s jednim stupnjem slobode, potrebno je konstrukciju s više stupnjeva slobode pretvoriti $\mathrm{u}$ ekvivalentni sustav s jednim stupnjem slobode. Primjenom faktora pretvorbe $\Gamma$ moguće je provesti pretvorbu sustava s više stupnjeva slobode u ekvivalentni sustav s jednim stupnjem slobode [1], [2], [5]:

$$
\Gamma=\frac{\Phi^{\mathrm{T}} \mathrm{m} 1}{\Phi^{\mathrm{T}} \mathrm{m} \Phi}=\frac{\sum m_{i} \Phi_{i}}{\sum m_{i} \Phi_{\mathrm{i}}^{2}}=\frac{m^{*}}{\sum m_{i} \Phi_{i}^{2}}
$$

Nakon određivanja krivulje kapaciteta, primjenom faktora pretvorbe $\Gamma$ određuje se pomak $D^{*}$ i sila $F^{*}$ za ekvivalentni sustav s jednim stupnjem slobode (Slika 3) [1], [5]:

$$
\begin{aligned}
D^{*} & =\frac{D_{\mathrm{t}}}{\Gamma} \\
F^{*} & =\frac{V}{\Gamma}
\end{aligned}
$$
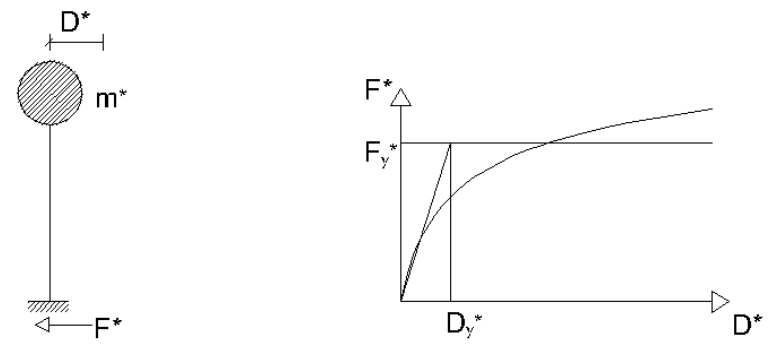

Slika 3. Ekvivalentni model s jednim stupnjem slobode (lijevo) i odgovarajući dijagram odnosa sila-pomak za ekvivalentni model (desno) (prema [1])

Elastični period $T^{*}$ idealiziranog sustava s jednim stupnjem slobode određuje se koristeći sljedeći izraz [1]:

$$
T^{*}=2 \pi \sqrt{\frac{m^{*} D_{y}^{*}}{F_{y}^{*}}}
$$

gdje je $m^{*}$ masa ekvivalentnog sustava $\mathrm{s}$ jednim stupnjem slobode. Primjenom izraza (6) određuje se ubrzanje na granici popuštanja $S_{a y}$, tako da se sila $F^{*}$ na granici popuštanja podijeli s masom ekvivalentnog sustava $\mathrm{s}$ jednim stupnjem slobode $m^{*}[1],[2]$, [5]:

$$
S_{a y}=\frac{F^{*}}{m^{*}}
$$


Zatim se procjenjuje potresni zahtjev za ekvivalentni sustav s jednim stupnjem slobode. Na Slici 4 prikazani su primjeri zahtijevanog spektra ubrzanje-pomak i dijagrami kapaciteta. Primjeri su dani za konstrukcije sa srednjim do dugim periodom osciliranja te za konstrukcije s relativno kratkim periodom osciliranja.
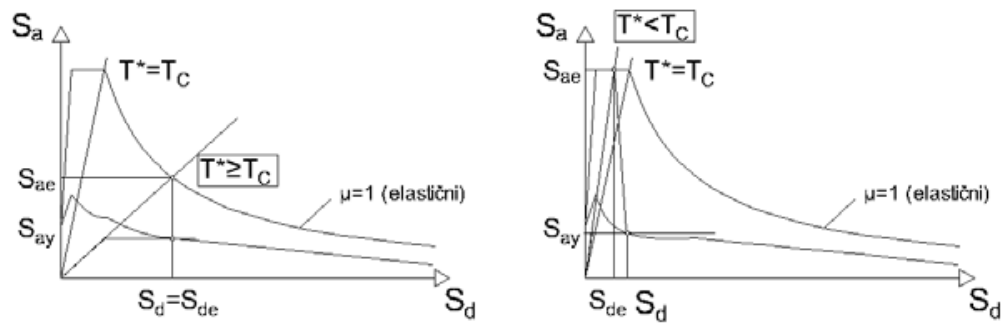

Slika 4. Elastični i neelastični zahtijevani spektri te dijagrami kapaciteta za konstrukcije sa srednjim i dugim periodima (lijevo) te konstrukcije s kratkim periodima (desno)

$\mathrm{Na}$ mjestu gdje radijalni pravac, odnosno elastični period $T^{*}$ idealiziranog sustava s jednim stupnjem slobode, presijeca elastični zahtijevani spektar određuje se zahtijevano elastično ubrzanje $S_{a e}$ i zahtijevani elastični pomak $S_{d e}$. Faktor redukcije $R_{\mu}$ se određuje pomoću izraza (8) kao omjer ubrzanja koja odgovaraju elastičnom i neelastičnom spektru odziva [1], pri čemu vrijedi:

$$
\begin{gathered}
\text { za } T^{*} \geq T_{\mathrm{C}} \quad S_{d}=S_{d e}\left(T^{*}\right) \\
\mu=R_{\mu} \\
R_{\mu}=\frac{S_{a e}\left(T^{*}\right)}{S_{a y}}
\end{gathered}
$$

Ako je elastični period $T^{*}$ manji od rubnog perioda $T_{C}$, zahtijevani neelastični pomak $S_{d}$ je različit od zahtijevanog elastičnog pomaka $S_{d e}$ pa se zahtijevana duktilnost $\mu$ računa pomoću sljedećeg izraza [1]:

$$
\begin{gathered}
\text { za } T^{*}<T_{\mathrm{C}} \quad \mu=\left(R_{\mu}-1\right) \frac{T_{\mathrm{C}}}{T^{*}}+1 \\
S_{d}=\mu D_{y}^{*}=\frac{S_{d e}}{R_{\mu}}\left(1+\left(R_{\mu}-1\right) \frac{T_{\mathrm{C}}}{T^{*}}\right)
\end{gathered}
$$

Nakon određivanja zahtijevanog pomaka sustava s jednim stupnjem slobode $S_{d}$, primjenjuje se faktor transformacije $\Gamma$ za proračun ciljanog pomaka $D_{\mathrm{t}}$ [1], [2], [5]: 


$$
D_{t}=\Gamma S_{d}
$$

Nadalje, lokalni potresni zahtjevi određuju se kao, primjerice, apsolutni i relativni pomaci katova te rotacije čvorova (Slika 5). Ciljani pomak se zadaje u računalnom programu kao najveći pomak koji će konstrukcija dosegnuti prilikom djelovanja bočnih potresnih sila. Horizontalne potresne sile se zadaju različito s obzirom na raspodjelu po visini konstrukcije (npr. trokutasto, jednoliko ili modalno).
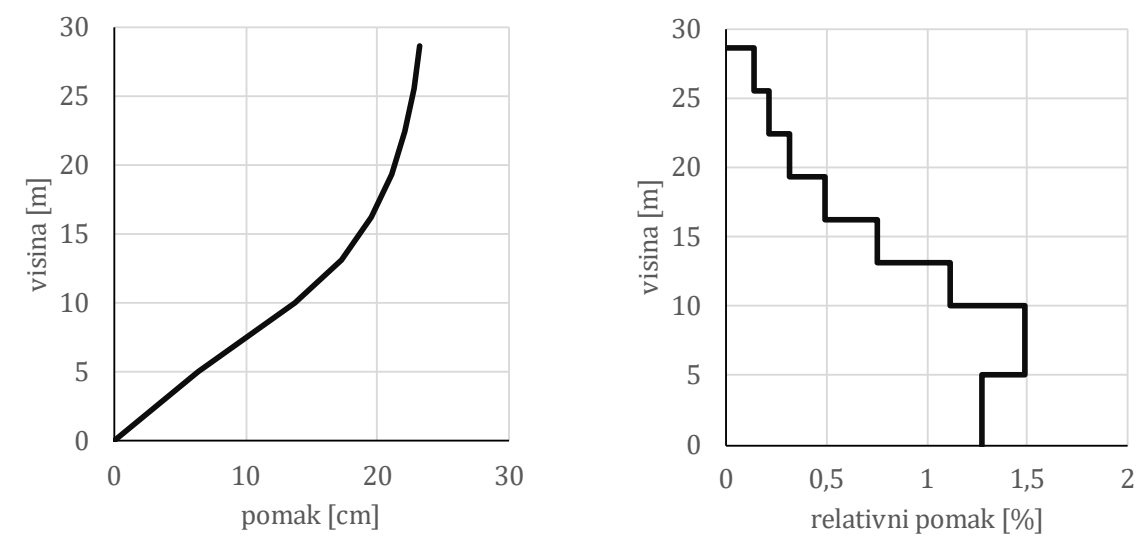

Slika 5. Apsolutni pomaci (lijevo) i relativni pomaci (desno)
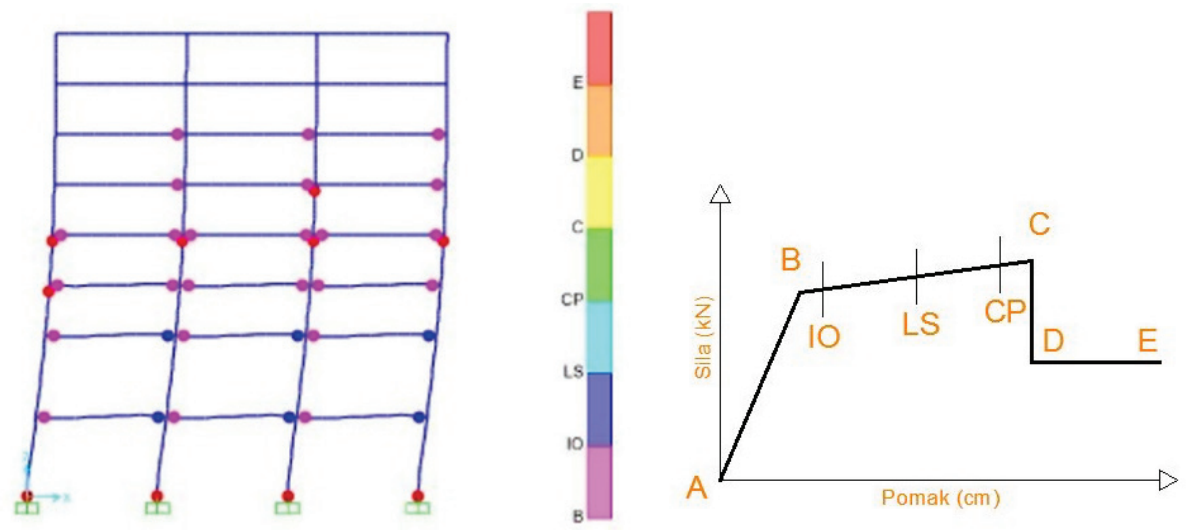

Slika 6. Mjesta nastanka plastičnih zglobova u konstrukciji i pripadajuće razine plastifikacije, tj. oštećenja

U posljednjem koraku provedbe metode N2 se pomoću potresnih zahtjeva (globalnih i lokalnih) procjenjuje ponašanje konstrukcije izložene monotono rastućem horizontalnom opterećenju. Mjesta nastanka plastičnih zglobova u konstrukciji prikazana su na Slici 6, gdje slova B, 
C, D i E redom označavaju početnu plastifikaciju zgloba, maksimalni kapacitet zgloba, zaostali kapacitet te potpuni slom, dok IO (en. immediate occupancy), LS (en. life safety) i CP (en. collapse prevention) označavaju trenutna stanja konstrukcije, i to redom stanje trenutne useljivosti, zaštite života te stanje pred rušenje (Slika 6).

\section{Opis promatranih konstrukcija}

U radu su promatrane dvije armiranobetonske konstrukcije. Obje promatrane konstrukcije su pravilne u tlocrtu i po visini te bez istaka i suženja.

\section{1. Četverokatna, dvorasponska okvirna konstrukcija}

Slika 7 prikazuje presjek i tlocrt konstrukcije opisane u [3]. Ukupna masa prostornog modela iznosi $345 \mathrm{t}$, dok ukupna masa ravninskog modela iznosi 109,5 t. Konstrukcija će se dalje u tekstu referirati kao K4R2, gdje K4 označava četiri kata, a R2 dva raspona. Konstrukcija je izrađena od betona razreda C25/30 i armature razreda S500, kako je definirano u [3]. Prvi period osciliranja konstrukcije iznosi oko 0,80 s [3].
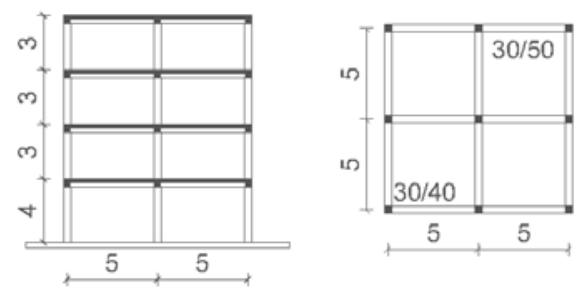

Slika 7. Presjek (lijevo) i tlocrt (desno) konstrukcije K4R2 (kotirano u metrima)

Stup okvira konstrukcije K4R2 ima dimenzije 30/40 cm (Slika 8), pri čemu je poprečni presjek postavljen tako da se duža stranica presjeka proteže paralelno s ravninom okvira. Unutar poprečnog presjeka stupa razmještena je glavna uzdužna armatura po obodu u količini od $8 \Phi 12$, a spone promjera $8 \mathrm{~mm}$ su postavljene duž osi stupa na razmaku od $250 \mathrm{~mm}$. Poprečni presjek grede je dimenzija 30x50 cm (Slika 8). Unutar poprečnog presjeka grede razmještena je uzdužna armatura u gornjoj zoni u količini od $3 \Phi 16$, dok je u donjoj zoni postavljena uzdužna armatura u količini od $2 \Phi 16$. Spone promjera $8 \mathrm{~mm}$ postavljene su u gredi na razmaku od 250 $\mathrm{mm}$. 

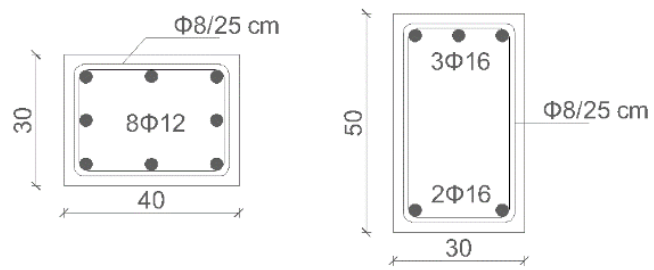

Slika 8. Poprečni presjek stupa (lijevo) i grede (desno) modela K4R2

\subsection{Osmerokatna, trorasponska okvirna konstrukcija}

Slika 9 prikazuje tlocrt i presjek osmerokatne, trorasponske armiranobetonske konstrukcije [1]. Ukupna masa prostornog modela iznosi 2886 t, a ukupna masa ravninskog modela 550 t. Konstrukcija će se dalje u tekstu referirati kao K8R3, gdje K8 označava osam katova, a R3 tri raspona.
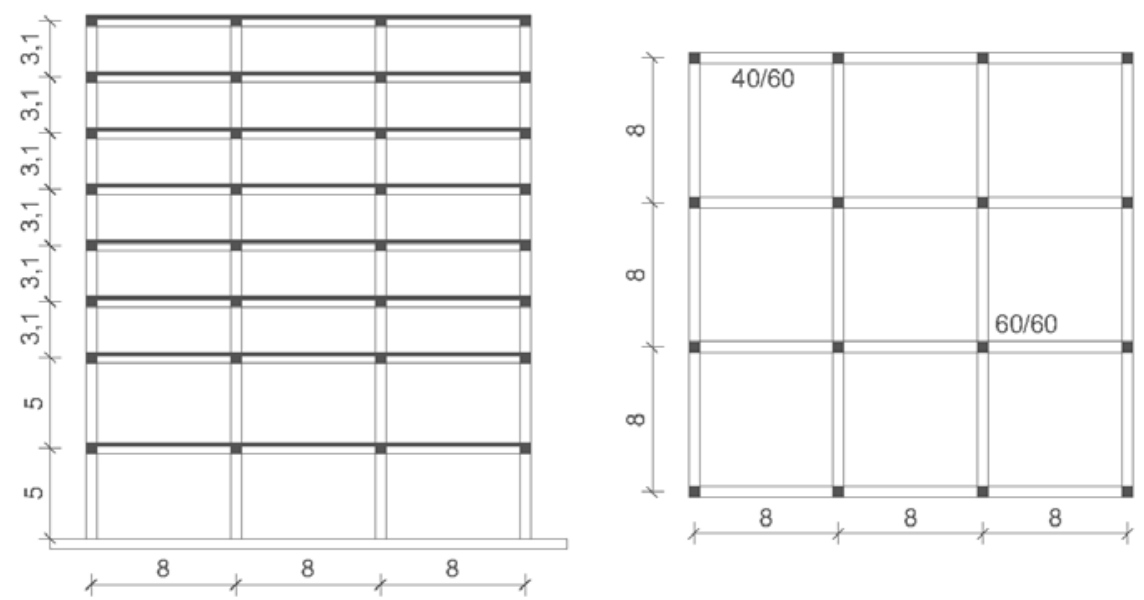

Slika 9. Presjek (lijevo) i tlocrt (desno) konstrukcije K8R3 (kotirano u metrima)

Konstrukcija je izrađena od betona razreda C30/37 i armature razreda B500, kako je definirano u [1]. Prvi period osciliranja konstrukcije iznosi oko 1,0 s [1]. Stup okvira konstrukcije K8R3 ima dimenzije 60/60 cm (Slika 10). Unutar poprečnog presjeka stupa razmještena je glavna uzdužna armatura po obodu u količini od $8 \Phi 20$, a spone promjera $8 \mathrm{~mm}$ i $10 \mathrm{~mm}$ su postavljene duž osi stupa na razmaku od $150 \mathrm{~mm}$. Poprečni presjek grede je dimenzija 40x60 cm (Slika 10). Unutar poprečnog presjeka grede razmještena je uzdužna armatura u gornjoj i donjoj zoni u jednakoj količini od $4 \Phi 20$. Spone promjera $8 \mathrm{~mm}$ su u gredi postavljene na uzdužnom razmaku od $150 \mathrm{~mm}$. 

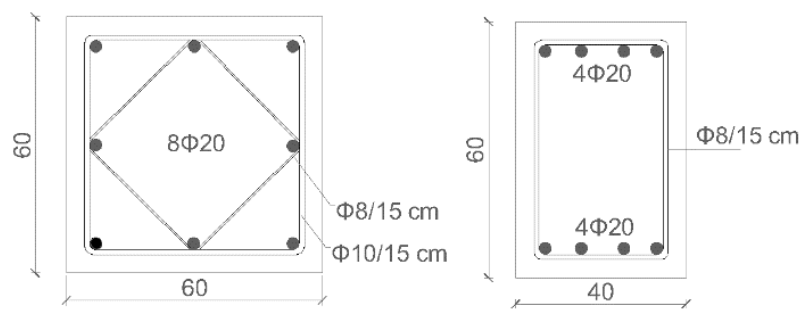

Slika 10. Poprečni presjek stupa (lijevo) i grede (desno) modela K8R3

\section{Sastavni dijelovi modela zgrada}

Promatrane konstrukcije su za potrebe istraživanja potresnog ponašanja modelirane primjenom računalnog programa SAP2000 [4]. U narednim poglavljima su detaljnije opisani ključni dijelovi modela koji omogućavaju njegovu ponovljivost. Plastični zglobovi su modelirani na dva različita načina, i to primjenom mogućnosti koje sadrži korišteni računalni program: kao točkasti i raspodijeljeni (vlaknasti). Valjanost modela izrađenoga u okviru ovoga rada je provjerena kroz usporedbu njihovih odziva s odzivom pandana objavljenih u dostupnoj literaturi. Na ovaj način je ujedno provjerena mogućnost primjene osnovnih, jednostavnih, načina modeliranja plastičnih zglobova u korištenom računalnom programu. Plastični zglobovi su dodani na krajeve elemenata modela na dužini koja iznosi $10 \%$ ukupne dužine elementa.

\subsection{Definiranje materijala}

Nelinearno ponašanje betona i čelika je definirano sukladno normi HRN EN 1992-1-1 [10], pri čemu je za modeliranje nelinearnog ponašanja betona korišten Manderov model, dok je za modeliranje nelinearnog ponašanja armature korišten jednostavni (Simple) model, definiran u računalnom programu SAP2000 [4]. Za beton je pretpostavljeno izotropno ponašanje, dok je za armaturni čelik pretpostavljeno jednoosno ponašanje. Sukladno normi HRN EN 1992-1-1 [10], usvojene su deformacije pri dostizanju vršne čvrstoće betona $\varepsilon_{\mathrm{c} 1}$ te maksimalna deformacija pri slomu betona $\varepsilon_{\text {cu1 }}$. Osnovna svojstva betona korištenih u radu su dana u Tablici 1 , gdje su $f_{\text {ck }}$ karakteristična tlačna čvrstoća betona, a $E_{\mathrm{cm}}$ sekantni modul elastičnosti betona. Poissonov koeficijent za beton je usvojen i jednak vrijednosti od 0,2. Modul elastičnosti za armaturni čelik je usvojen i jednak vrijednosti od $200000 \mathrm{~N} / \mathrm{mm}^{2}$. U numeričkim modelima je dopušteno deformiranje ovijenog betona u stupovima do deformacije od $5 \%$. 
Tablica 1. Svojstva betona (prema [10])

\begin{tabular}{|c|c|c|c|c|}
\hline Razred betona & $f_{\mathrm{ck}}\left(\mathrm{N} / \mathrm{mm}^{2}\right)$ & $E_{\mathrm{cm}}\left(\mathrm{N} / \mathrm{mm}^{2}\right)$ & $\varepsilon_{\mathrm{c} 1}(\% 0)$ & $\varepsilon_{\mathrm{cu} 1}(\%)$ \\
\hline $\mathrm{C} 25 / 30$ & 25 & 31000 & 2,1 & 3,5 \\
\hline $\mathrm{C} 30 / 37$ & 30 & 33000 & 2,2 & 3,5 \\
\hline
\end{tabular}

\subsection{Definiranje potresnog opterećenja}

Horizontalno, monotono rastuće opterećenje za simuliranje potresnog djelovanja na konstrukciju modelirano je sukladno tri preporučena pristupa opisana u pregledanoj literaturi [7]: trokutasta (linearna) raspodjela, jednolika raspodjela te modalna raspodjela, koja odgovara prvome obliku osciliranja modela. U Tablici 2 prikazana je raspodjela horizontalnih sila za modele K4R2-2D, K4R2-3D, K8R3-2D te K8R3-3D, pri čemu 2D označava ravninski model, a 3D prostorni model. Za obje konstrukcije je pretpostavljeno temeljno tlo razreda B s vršnim ubrzanjem podloge od 0,3 g. Ovo je očekivano ubrzanje za Republiku Hrvatsku za povratni period od 475 godina [1].

Tablica 2. Raspodjela horizontalnih sila za modele K4R2-2D/3D i K8R3-2D/3D

\begin{tabular}{|c|c|c|c|c|c|c|}
\hline \multirow{2}{*}{ Kat } & \multicolumn{2}{|c|}{$\begin{array}{c}\text { Trokutasto } \\
\text { 2D/3D }\end{array}$} & \multicolumn{2}{c|}{$\begin{array}{c}\text { Jednoliko } \\
\text { 2D } / 3 \mathrm{D}\end{array}$} & \multicolumn{2}{c|}{ Modalno } \\
\cline { 2 - 7 } & K4R2 & K8R3 & K4R2 & K8R3 & K4R2 & K8R3 \\
\hline & $0,29 / 0,31$ & $0,19 / 0,19$ & $1 / 1$ & $1 / 1$ & $0,74 / 0,49$ & $0,26 / 0,26$ \\
\hline 2 & $0,51 / 0,53$ & $0,39 / 0,39$ & $1 / 1$ & $1 / 1$ & $0,85 / 0,73$ & $0,60 / 0,60$ \\
\hline 3 & $0,73 / 0,76$ & $0,46 / 0,46$ & $1 / 1$ & $1 / 1$ & $0,92 / 0,9$ & $0,67 / 0,68$ \\
\hline 4 & $1 / 1$ & $0,57 / 0,57$ & $1 / 1$ & $1 / 1$ & $1 / 1$ & $0,78 / 0,79$ \\
\hline 5 & - & $0,67 / 0,67$ & - & $1 / 1$ & - & $0,86 / 0,88$ \\
\hline 6 & - & $0,78 / 0,78$ & - & $1 / 1$ & - & $0,93 / 0,94$ \\
\hline 7 & - & $0,89 / 0,89$ & - & $1 / 1$ & - & $0,97 / 0,97$ \\
\hline 8 & - & $1 / 1$ & - & $1 / 1$ & - & $1 / 1$ \\
\hline
\end{tabular}

\subsection{Vlastita težina}

Vlastita težina konstrukcije sadrži težinu konstrukcijskih elemenata. Specifična težina armiranog betona je usvojena i jednaka vrijednosti od $25 \mathrm{kN} / \mathrm{m}^{3}$.

Osim vlastitom težinom, ravninski i prostorni modeli K8R3 su opterećeni dodatnim opterećenjem postavljenim na grede, a kako bi se obuhvatila masa konstrukcije opisana u [1]. Tako su grede prizemlja i prvog 
kata modela K8R3 opterećene jednolikim raspodijeljenim opterećenjem u iznosu od 19,47 kN/m, dok su grede preostalih šest katova opterećene jednolikim raspodijeljenim opterećenjem u iznosu od 18,08 kN/m.

Modeli K4R2 su, osim vlastitom težinom, također opterećeni dodatnim opterećenjem postavljenim na grede, a kako bi se u cijelosti obuhvatila masa konstrukcije opisana u [3]. Tako su grede prizemlja, 1. i 2. kata modela K4R2 opterećene jednolikim raspodijeljenim opterećenjem u iznosu od 14,06 kN/m, dok su grede posljednjeg kata opterećene jednolikim raspodijeljenim opterećenjem u iznosu od 14,22 kN/m.

\subsection{Točkasti plastični zglobovi}

Za stupove su odabrani i proračunani parametri zgloba sukladno tablici 6-8 prema FEMA 356 [11], uz uvjetovano ponašanje dvoosnim savijanjem i uzdužnom silom. Uz to je za zglobove stupova uključen doprinos spona kako bi se ostvario učinak ovijenosti betona. S druge strane, za grede su odabrani i proračunani parametri zgloba sukladno Tablici 6-7 prema FEMA 356 [11], uz uvjetovano ponašanje jednoosnim savijanjem oko jače osi. Za grede nije uključen doprinos spona.

\subsection{Vlaknasti plastični zglobovi}

Pri definiranju vlaknastih (Fiber) plastičnih zglobova, poprečni presjek grede i stupa su izdijeljeni na minimalni preporučeni broj betonskih vlakana [4], što iznosi devet betonskih vlakana, uz dodatna čelična vlakna, pri čemu svako čelično vlakno predstavlja po jednu uzdužnu armaturnu šipku ugrađenu u element. Ponašanje vlaknastog plastičnog zgloba je uvjetovano dvoosnim savijanjem i uzdužnom silom, a kontrolirano je preko deformacije. Slika 11 prikazuje dijagrame moment savijanja-zakrivljenost za poprečne presjeke modela K4R2 (v. Sliku 8) i K8R3 (v. Sliku 10), proračunane u programu SAP2000 [4].
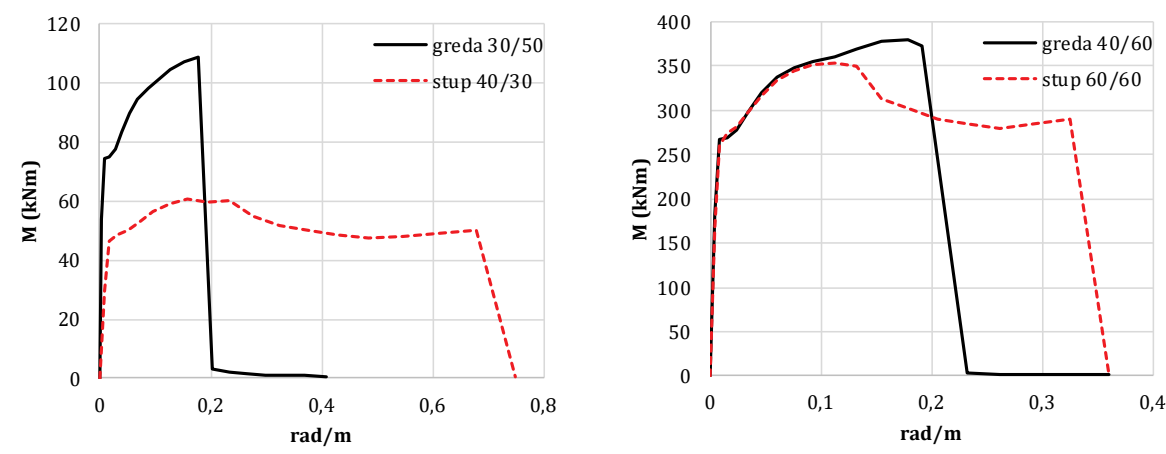

Slika 11. Dijagrami moment savijanja-zakrivljenost za poprečne presjeke modela K4R2 (lijevo) i modela K8R3 (desno) 


\section{Rezultati}

U narednim potpoglavljima dan je sažeti prikaz najvažnijih rezultata dobivenih proračunom. Zbog ograničenog prostora, $u$ nastavku je dan grafički prikaz rezultata dobivenih proračunom i to samo za numeričke modele opterećene trokutastom raspodjelom horizontalnog opterećenja. Rezultati proračuna za ostale raspodjele opterećenja su dani u [12]. Prikazani rezultati u nastavku povezani su s nazivima numeričkih modela, gdje se $S$-vlakna odnosi na numerički model čiji stupovi imaju poprečne presjeke izdijeljene u vlakna, SiG-vlakna na numerički model čiji stupovi i grede imaju poprečne presjeke izdijeljene u vlakna, a SiG-vlakna-PA na numerički model čiji stupovi i grede imaju poprečne presjeke izdijeljene u vlakna uz uključen doprinos P-delta učinaka. S-FEMA se odnosi na numerički model čiji stupovi imaju plastične zglobove definirane u skladu s preporukama u FEMA 356 [11], dok se SiG-FEMA odnosi na numerički model čiji stupovi i grede imaju plastične zglobove definirane u skladu s preporukama u FEMA 356 [11]. Idealizirana krivulja (Slika 11 i 12) je izrađena u skladu sa [7]. Ako nije drugačije naglašeno u opisu modela, grede nemaju mogućnost plastificiranja, a P-delta učinci nisu uzeti u obzir.

\subsection{Kapacitet i otpornost konstrukcija zgrada}

Oblik raspodjele horizontalnog opterećenja ne utječe značajno na konačnu vrijednost otpornosti konstrukcije $F_{\mathrm{y}}$, niti na vrijednost pomaka pri popuštanju $D_{\mathrm{y}}$ (Tablica 3 ). No, uočeno je da vrijednost faktora transformacije $\Gamma$ ovisi o obliku raspodjele horizontalnog opterećenja. Ovisno o odabranoj raspodjeli horizontalnog opterećenja, faktor transformacije se kreće između vrijednosti 1,00 i 1,40 (Tablica 3). Uz osvrt na Slike 7 i 9, koje prikazuju presjeke i tlocrte promatranih konstrukcija, te pregledom Tablice 3, ustanovljeno je da se odziv 3D pravilne okvirne konstrukcije može dovoljno točno procijeniti i zbrojem rješenja dobivenih za 2D okvire od kojih je sačinjena 3D konstrukcija.

Tablica 3. Vrijednosti otpornosti pri popuštanju $F_{y}$, pomaka pri popuštanju $D_{y} i$ faktora transformacije $\Gamma$ za različite raspodjele horizontalnog opterećenja

\begin{tabular}{|c|c|c|c|c|c|c|c|c|c|}
\hline \multirow{2}{*}{$\begin{array}{c}\text { Oznaka } \\
\text { modela }\end{array}$} & \multicolumn{3}{|c|}{$\begin{array}{c}\text { Trokutasto } \\
\text { horizontalno } \\
\text { opterećenje }\end{array}$} & \multicolumn{3}{c|}{$\begin{array}{c}\text { Jednoliko } \\
\text { horizontalno } \\
\text { opterećenje }\end{array}$} & \multicolumn{3}{c|}{$\begin{array}{c}\text { Modalno } \\
\text { horizontalno } \\
\text { opterećenje }\end{array}$} \\
\cline { 2 - 11 } & $\begin{array}{c}F_{\mathrm{y}} \\
(\mathrm{kN})\end{array}$ & $\begin{array}{c}D_{\mathrm{y}} \\
(\mathrm{mm})\end{array}$ & $\Gamma$ & $\begin{array}{c}F_{\mathrm{y}} \\
(\mathrm{kN})\end{array}$ & $\begin{array}{c}D_{\mathrm{y}} \\
(\mathrm{mm})\end{array}$ & $\Gamma$ & $\begin{array}{c}F_{\mathrm{y}} \\
(\mathrm{kN})\end{array}$ & $\begin{array}{c}D_{\mathrm{y}} \\
(\mathrm{mm})\end{array}$ & $\Gamma$ \\
\hline K4R2-2D & 140 & 40 & 1,31 & 135 & 50 & 1,00 & 135 & 50 & 1,08 \\
\hline K4R2-3D & 380 & 50 & 1,32 & 400 & 50 & 1,00 & 380 & 50 & 1,20 \\
\hline K8R3-2D & 550 & 100 & 1,39 & 610 & 100 & 1,00 & 570 & 110 & 1,22 \\
\hline K8R3-3D & 2450 & 125 & 1,39 & 2700 & 110 & 1,00 & 2500 & 110 & 1,20 \\
\hline
\end{tabular}


Slike 12 i 13 pokazuju da krutost modela značajno ovisi o odabiru metode za modeliranje sposobnosti konstrukcijske plastifikacije. Iako su dijelovi modela sa sposobnošću plastifikacije modelirani slijedeći preporuke u pregledanoj literaturi, odziv konstrukcije je u određenim slučajevima izrazito različit s obzirom na odabranu metodu (npr. Slika 13).

Veću krutost pokazuju modeli za koje su plastični zglobovi definirani prema prijedlogu FEMA-e, u odnosu na modele za koje je plastifikacija omogućena popuštanjem vlakana. Kako je već ranije spomenuto, poprečni presjeci su podijeljeni na najmanji preporučeni broj vlakana. U tom kontekstu postoji potreba za provjerom ponašanja numeričkih modela čiji poprečni presjeci sadrže veći broj vlakana.
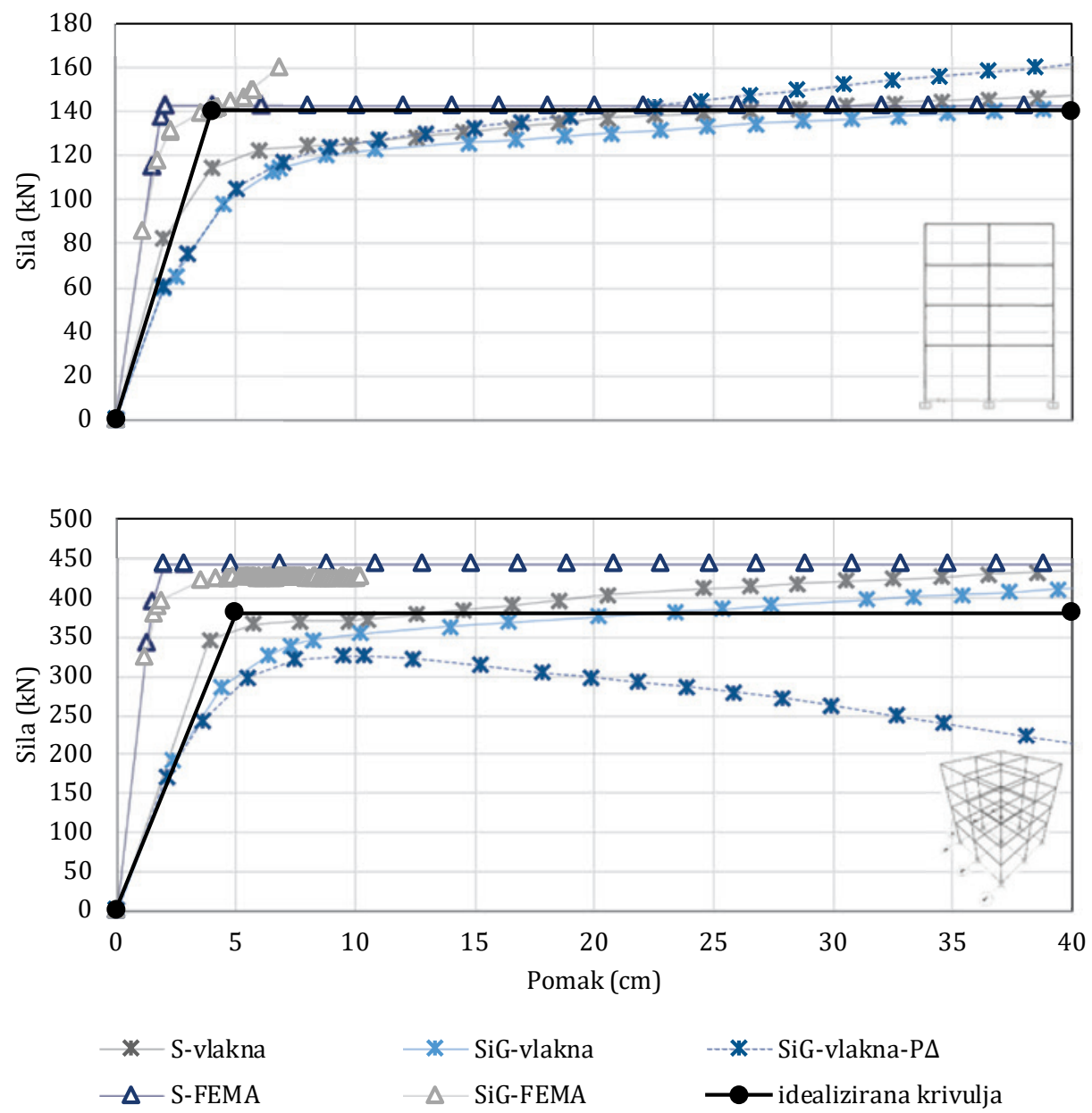

Slika 12. Krivulje kapaciteta za model K4R2-2D (gore) i model K4R2-3D (dolje), oba opterećena trokutastom raspodjelom horizontalnog opterećenja 
Idealizirana krivulja (Slike 12 i 13) je izrađena u skladu sa [7], pri čemu je ona određena isključivo za numeričke modele čiji stupovi i grede imaju poprečne presjeke izdijeljene u vlakna (modeli: SiG-vlakna). Ovi modeli su odabrani jer pokazuju najmanju nosivost, čime se ide na stranu sigurnosti konstrukcija koje bi bile izvedene. Usporede li se krivulje kapaciteta za zgradu s osam katova (Slika 13) može se primijetiti izraženije rasipanje rezultata u odnosu na krivulje kapaciteta određene za zgradu s četiri kata (Slika 12). Nadalje, ne postoji jasan trend utjecaja P-delta učinaka na odziv zgrade (Slika 12 i 13). Stoga autori zaključuju da u tome kontekstu treba provesti detaljnije istraživanje, primjerice, na većem fondu zgrada te na zgradama različitih visina i katnosti.
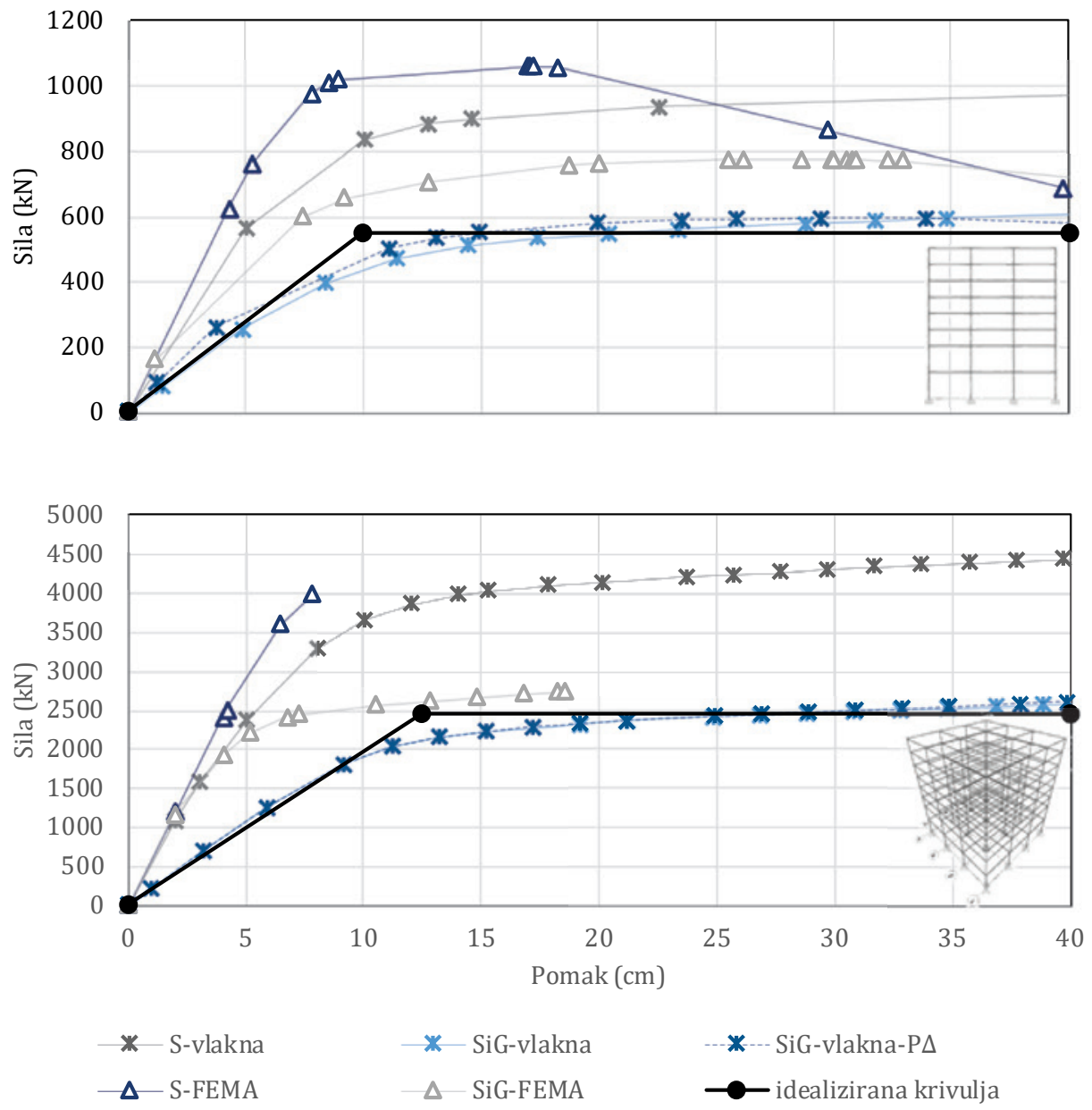

Slika 13. Krivulje kapaciteta za model K8R3-2D (gore) i model K8R3-3D (dolje), oba opterećena trokutastom raspodjelom horizontalnog opterećenja 


\subsection{Ciljani pomaci}

U Tablici 4 je dan pregled vrijednosti ciljanog pomaka $D_{\text {t }}$, određenih za promatrane konstrukcije, i to za tri različite raspodjele horizontalnog opterećenja po visini građevine. Vrijednosti pomaka su određene na numeričkim modelima konstrukcija za koje su plastični zglobovi definirani koristeći poprečne presjeke izdijeljene u vlakna. Za te modele je definirana i idealizirana krivulja kapaciteta. Ukupna visina promatrane četverokatne zgrade, mjereno od gornje plohe temeljne ploče, iznosi $13 \mathrm{~m}$, dok visina promatrane osmerokatne zgrade iznosi $29 \mathrm{~m}$. Stavljanjem u odnos ciljanog pomaka dobivenog proračunom i ukupne visine zgrade uočeno je da ciljani pomak iznosi 1,0 $\pm 0,2 \%$ ukupne visine zgrade.

Tablica 4. Vrijednosti ciljanog pomaka $D_{t}$ za različite raspodjele horizontalnog opterećenja

\begin{tabular}{|l|c|c|c|c|}
\hline $\begin{array}{l}\text { Raspodjela horizontalnog } \\
\text { opterećenja }\end{array}$ & \multicolumn{4}{|c|}{ Ciljani pomak $D_{\mathrm{t}}(\mathrm{mm})$} \\
\hline Oznaka modela & K4R2-2D & K4R2-3D & K8R3-2D & K8R3-3D \\
\hline Trokutasta & 131 & 152 & 236 & 285 \\
\hline Jednolika & 145 & 140 & 210 & 218 \\
\hline Modalna & 146 & 162 & 232 & 252 \\
\hline
\end{tabular}

\section{Zaključak}

Rad obuhvaća parametarsku studiju i primjenu brze nelinearne metode $\mathrm{N} 2$ za ocjenu potresnog ponašanja četverokatne i osmerokatne armiranobetonske zgrade. U istraživanju su korištene tri raspodjele horizontalnog opterećenja po visini građevine, a kojim se simulira djelovanje potresnim silama: trokutasta (linearna), jednolika i modalna. Također, istražen je utjecaj P-delta učinka na ponašanje promatranih konstrukcija te način modeliranja sposobnosti plastificiranja konstrukcijskih elemenata. Za svaku promatranu konstrukciju je provedena modalna analiza i nelinearni pseudo-statički proračun, a za proračun je korišten računalni program SAP2000. Analiza rezultata istraživanja je ukazala na sljedeće:

1. oblik raspodjele horizontalnog opterećenja ne utječe značajno na konačnu vrijednost otpornosti konstrukcije niti na vrijednost pomaka pri popuštanju

2. vrijednost faktora transformacije ovisi o obliku raspodjele horizontalnog opterećenja 
3. odziv 3D pravilne okvirne konstrukcije se može dovoljno točno procijeniti zbrojem rješenja dobivenih za 2D okvire od kojih je 3D konstrukcija sačinjena

4. ciljani pomak iznosi $1,0 \pm 0,2 \%$ ukupne visine zgrade

5. krutost modela značajno ovisi o odabiru metode za modeliranje sposobnosti konstrukcijske plastifikacije

6. ne postoji jasan trend utjecaja P-delta učinaka na odziv zgrade te $u$ tome kontekstu treba provesti detaljnije istraživanje, primjerice, na većem fondu zgrada te na zgradama različitih visina i katnosti.

Zahvala. Ovaj rad je proveden u okviru projekta "Pendularum" $i$ potpomognut financijskom potporom br. 15-04 Građevinskog $i$ arhitektonskog fakulteta Osijek.

\section{Literatura}

[1] Čaušević, M., (2014) Dinamika konstrukcija: potresno inženjerstvo, aerodinamika, konstrukcijske euronorme. Golden marketing - Tehnička knjiga, Zagreb

[2] Mitrović, S., i Čaušević, M. (2009). 'Nelinearni statički seizmički proračuni konstrukcija', Građevinar, 61(06.), str. 521-531. Preuzeto s: https://hrcak. srce.hr/40580 (Datum pristupa: 11.11.2019.)

[3] Fardis, M.N., Carvalho E.C., Fajfar P., Pecker A. (2015) Seismic Design of Concrete Buildings to Eurocode 8, Taylor \& Francis Group

[4] CSI (Computers and Structures Inc.) (2016) CSI Analysis Reference Manual for SAP2000, ETABS, SAFEand CsiBridge, Berkeley, California, USA

[5] Čaušević, M., i Zehentner, E. (2007). 'Nelinearni seizmički proračun konstrukcija prema normi EN 1998-1: 2004', Građevinar, 59(09.), str. 767777. Preuzeto s: https://hrcak.srce.hr/17739 (Datum pristupa: 11.11.2019.)

[6] Fajfar, P., Gašperšič, P., (1996) The N2 method for the Seismic Damage Analysis of RC Buildings. Earthquake Engineering and Structural Dynamics, 25 (1), pp. 31-46

[7] Cerovečki, A., Kraus, I., Morić, D. (2018). Metoda N2 za projektiranje zgrada, Građevinar, 70 (6), 509-518, doi: https://doi.org/10.14256/JCE.2324.2018

[8] Cerovečki, A., i Kraus, I. (2019). 'Fundamental Period and Damping of Experimentally Tested Reinforced-Concrete Building under Different Damage Levels', Engineering Review, 39(1), str. 105-114. https://doi. org/10.30765/er.39.1.11

[9] Kraus, I., Morić, D., i Netinger, I. (2011). 'Usporeba potresnog odziva armiranobetonskih zgrada od nekonvencionalnih betona', Electronic Journal of the Faculty of Civil Engineering Osijek-e-GFOS, 2(3), str. 1-13. Preuzeto s: https://hrcak.srce.hr/74400 (Datum pristupa: 11.11.2019.) 
[10] HRN EN 1992-1-1, Eurokod 2. (2008) Projektiranje betonskih konstrukcija 1-1. dio: Opća pravila i pravila za zgrade. Zagreb: HZN.

[11] FEDERAL EMERGENCY MANAGEMENT AGENCY (FEMA) (2000). NHERP. Guidelines for the Seismic Rehabilitation of Buildings (FEMA 356), Washington, D.C, U.S.A.

[12] Ivanko, A. M. (2019). 'Parametarska studija nelinearnog ponašanja konstrukcija podvrgnutih monotono rastućem bočnom opterećenju', Diplomski rad, Sveučilište Josipa Jurja Strossmayera u Osijeku, Građevinski i arhitektonski fakultet Osijek, dostupno na: https://urn.nsk.hr/ urn:nbn:hr:133:587134 (10.3. 2020.) 
